V. Andriiv, Dr of Law, Prof.

Taras Shevchenko National University of Kyiv, Kyiv, Ukraine

\title{
AGE FEATURES OF EMPLOYEES AND THEIR REGULATION UNDER INTERNATIONAL LABOUR LEGISLATION
}

The article analyses international legal acts that regulate the labour relations of certain categories of workers, as well as related problems. Their distinctive feature is the age that a person has reached at the time of entering into such a legal relationship.

The peculiarities of such regulation are determined; its characteristic features are specified.

Due to the fact that age is one of the legal facts that affect the legal status of the employee, an attempt is made to distinguish between age groups of employees and to identify features of their legal status in the employment relationship.

The methodological basis of the study includes general and special methods of cognition. The dialectical method examines the problems of legal regulation of international norms on the use of hired labour of minors and the elderly and their relationship with a number of trends that have different effects on international labour law. Formal-logical and systematic methods are used to study the content of international legal acts governing labour relations of minors and the elderly.

The main result of the study is the regulation in international legal acts of relations concerning the use of hired labour of minors and the elderly, improving its conditions, protection against discrimination and creating conditions for the free exercise of their ability to work within national laws, for comparative legal analysis and finding ways to improve existing systems. The article also pays attention to the content, significance and features of the basic principles for the use of hired labour of minors and the elderly, the establishment by member states of the minimum age for employment.

Keywords: labour, employee, international legal acts, age, child labour, children, adolescents, elderly workers, employment, working conditions, legal protection.

Bulletin of Taras Shevchenko National University of Kyiv.

Legal Studies, 2021; 1 (116): 11-14

УДК: 349.2

DOI: https:doi.org/10.17721/1728-2195/2021/1.116-2
ISSN 1728-2195

(C) Taras Shevchenko National University of Kyiv,

Publishing center "Kyiv University", 2020

Т. Вахонєва, д-р юрид. наук, проф. Інституту права ORCID ID: 00000000234953622

Київський національний університет імені Тараса Шевченка, Київ, Україна

\section{ПРАВОВИЙ СТАТУС І КВАЛІФІКАЦІЙНІ ВИМОГИ ДО ФАРМАЦЕВТИЧНИХ ПРАЦІВНИКІВ}

Досліджуються особливості правового статусу фармацевтичних працівників і визначається місце фармацевтичної діяльності у сфері охорони здоров'я. Фармацевтичні працівники розглядаються як окрема категорія працівників охорони здоров'я поряд із медичними працівниками та працівниками, що працюють у сфері здійснення реабілітаційної діяльності. Визначаються закріплені законодавством кваліфікаційні вимоги до фармацевтичних працівників залежно від сфери та виду фармацевтичної діяльності. До фармацевтичних працівників належать професіонали та фахівці, які працюють на підставі трудового договору у сфері виробництва, оптової (роздрібної) торгівлі й імпорту лікарських засобів і відповідають ліцензійним та іншим нормативним вимогам, що врегульовують організацію $і$ функціонування фармацевтичної діяльності. Досліджуються окремі ліцензійні умови здійснення різних видів фармацевтичної діяльності та співвідношення їхніх норм з іншими нормативними актами.

Вказується на необхідність удосконалення чинного законодавства у сфері регулювання фармацевтичних відносин і розроблення дієвих юридичних механізмів забезпечення ефективного контролю за такою діяльністю. Необхідним є прийняття спеціального закону про фармацевтичну діяльність; законодавче визначення фармацевтичної діяльності з основними її ознаками; законодавче визначення всіх основних видів фармацевтичної діяльності, умов її здійснення та суб'єктів; детальна регламентація правового та трудо-правового статусу фармацевтичних працівників; особлива увага та контроль повинен приділятися питанням визначення кваліфікації фармацевтичних працівників, підтримці їхнього безперервного професійного навчання та встановленню якісного контролю за якістю їх роботи.

Ключові слова: фармацевтична діяльність, фармацевтичні працівники, кваліфікаційні вимоги, кваліфікаційні характеристики, ліцензійні вимоги.

ВСТУП. Виходячи із сутності та напрямів фармацевтичної діяльності, фрармацевтичні працівники є працівниками охорони здоров'я, але не належать до категорії медичних працівників. Водночас фрармацевтична діяльність $€$ настільки важливою ланкою у сфері забезпечення належного рівня охорони здоров'я, що у відповідній системі, фрармацевтична діяльність займає належне місце поряд із медичною діяльністю, і діяльністю у сорері надання реабілітаційної допомоги. Варто відзначити, що, незважаючи на безспірну важливість і значущість, законодавство про охорону здоров'я залишається не сорормованим у повному обсязі й абсолютно неупорядкованим. Наприклад, відсутнє визначення фрармацевтичної діяльності та ії складових, залишаються нормативно не закріпленими принципи такої діяльності, потребують уточнення всі можливі суб'єкти фрармацевтичної діяльності. Визначитися 3 окремими видами та напрямами фармацевтичної діяльності можна завдяки Закону України "Про лікарські засоби" [1], однак зазначений нормативний акт, звичайно, ураховуючи сфреру його дії, не визначає правового статусу фармацевтичних працівників, які $є$ лише окремою групою серед багатьох інших суб'єктів фармацевтичної діяльності. Проте фармацевтичні працівники є численною групою учасників фрармацевтичних відносин, які в різних її ссрерах виконують різні професійні функції, але, загалом, забезпечують внутрішнє обслуговування та зовнішнє фрнкціонування фрармацевтичної галузі.

ВИКЛАД ОСНОВНОГО МАТЕРІАЛУ. УраховУЮчИ положення основних нормативних актів у зазначеній сфері, визначимо фармацевтичну діяльність як різновид господарської діяльності, яка здійснюється суб'єктами господарювання на підставі ліцензії на відповідний вид діяльності з метою виробництва, оптової та роздрібної торгівлі й імпорту лікарських засобів за умови виконання (дотримання) кадрових, організаційних, інших спеціальних вимог, встановлених законодавством.

Відповідно до "Ліцензійних умов провадження господарської діяльності з виробництва лікарських засобів, оптової та роздрібної торгівлі лікарськими засобами, 
імпорту лікарських засобів (крім активних фармацевтичних інгредієнтів)" [2] провадження вищезазначеної діяльності здійснюється через:

- для виробництва лікарських засобів (промислового) - виробничу дільницю із зазначенням переліку лікарських фрорм, складську зону (приміщення для зберігання, склад), зону контролю якості, зону здійснення видачі дозволу на випуск лікарських засобів;

- для виробництва (виготовлення) лікарських засобів в умовах аптеки - аптеку;

- для оптової торгівлі лікарськими засобами - аптечний склад (базу);

- для роздрібної торгівлі лікарськими засобами аптеку, аптечний пункт;

- для імпорту лікарських засобів (крім активних фрармацевтичних інгредієнтів) - складську зону (приміщення для зберігання, склад), зону контролю якості, зону здійснення видачі дозволу на випуск (реалізацію) серії лікарського засобу.

Усі види фармацевтичної діяльності підлягають ліцензуванню, що зобов'язує суб'єктів підприємницької діяльності дотримуватися норм ліцензійного законодавства, зокрема, під час здійснення фармацевтичної діяльності - спеціальних ліцензійних вимог (умов), що містяться в Законі України "Про лікарські засоби" [1], Основах законодавства України про охорону здоров'я [3] та інших Законах і підзаконних нормативних актах, основним із яких $є$ "Ліцензійні умови провадження господарської діяльності з виробництва лікарських засобів, оптової та роздрібної торгівлі лікарськими засобами, імпорту лікарських засобів (крім активних фрармацевтичних інгредієнтів)" [2].

Ліцензійні умови охоплюють практично всі питання організації різних видів фармацевтичної діяльності суб'єктами господарювання (ліцензіатами), зокрема вміщує кваліфікаційні й інші вимоги до фармацевтичних працівників. Основні такі вимоги викладено у ст. 74 Основ законодавства України про охорону здоров'я [3], яка закріплює, що провадити фармацевтичну діяльність можуть особи, які мають відповідну спеціальну освіту та відповідають єдиним кваліфікаційним вимогам. Водночас єдині кваліфрікаційні вимоги до осіб, які провадять певні види фармацевтичної діяльності, встановлюються центральним органом виконавчої влади, що забезпечує фоормування державної політики у сфері охорони здоров'я. Відповідальність за дотримання зазначених кваліфікаційних вимог несуть керівники закладів охорони здоров'я, реабілітаційних закладів, відділень, підрозділів, а також органи, яким надано право видавати ліцензію на провадження відповідних видів господарської діяльності.

Єдині кваліфрікаційні вимоги містяться насамперед у Довіднику кваліфікаційних характеристик професій, який призначається для розв'язання питань раціонального розподілу праці та правильного використання персоналу згідно з фахом і кваліфікацією; визначення завдань, обов'язків і відповідальності працівників галузі. Кваліфікаційні вимоги передбачають насамперед визначення освітньо-кваліфікаційний рівня працівника, напрям і спеціальність його підготовки, підвищення кваліфікації, стаж роботи.

Випуск 78 "Охорона здоров'я" Довідника кваліфікаційних характеристик професій [4] працівників розроблено 3 урахуванням змін державних стандартів щодо класифікації професій і чинної номенклатури посад медичних працівників системи Міністерства охорони здоров'я України. Зазначений "Випуск" побудовано відповідно до структури Класифрікатора профресій (ДК 003:2010) [5]. До нього ввійшли кваліфікаційні характеристики керів- ників (рівень спеціаліста та магістра), професіоналів (рівень спеціаліста або магістра), фахівців (рівень молодшого спеціаліста, бакалавра або спеціаліста, що проходить післядипломну підготовку (стажування)), технічних службовців і робітників (рівень повної або базової загальної середньої освіти та професійної підготовки на робочому місці), які є специфічними для фармацевтичної галузі.

Отже, загальний перелік посад працівників у сфері охорони здоров'я, що міститься в Довіднику кваліфікаційних характеристик профресій (вип. 78) [4], до фармацевтичних працівників належать особи, які мають освіту:

1) керівники за напрямом підготовки "Фармація" і спеціальністю "Фармація" (завідувач аптеки, завідувач аптечної бази, завідувач лабораторії й ін.);

2) профессіонали в галузі фрармації за напрямом підготовки "Фармація" та спеціальностями "Фармація", "Клінічна фрармація", "Технологія парфумерно-косметичних засобів" (провізор, провізор-аналітик, клінічний провізор, провізор-косметолог та ін.);

3) фахівці за напрямом підготовки "Фармація" та спеціальностями "Фармація", "Аналітичний контроль якості хімічних лікарських сполук" (фармацевт, лаборант та ін.).

У процесі зарахування на посади провізорів та середнього фармацевтичного персоналу варто також ураховувати положення "Переліку вищих медичних навчальних закладів, підготовка й отримання звання в яких дають право займатися медичною і фармацевтичною діяльністю" [6]. Вказаний перелік визначає провізорські посади та посади середнього фармацевтичного персоналу, що належать до фармацевтичних працівників, із вказівкою на: вимоги до спеціальності; назву навчального закладу; фракультет (відділення); спеціальність (кваліфікацію), що дає право обіймати посади фармацевтичних працівників; посади, які може обіймати спеціаліст в установах охорони здоров'я. "Фармація" $\epsilon$ основною спеціальністю фармацевтичних працівників, але фракультети навчальних закладів передбачають можливість навчання не лише на фармацевтичному фракультеті, а також на лікувальному, біологічному, хімічному, хіміко-фрармацевтичному й ін. Отже, щодо окремих посад, фармацевтичні працівники можуть мати медичну, хіміко-біологічну й іншу освіту. Виходячи зі змісту та видів фармацевтичної діяльності, такий підхід $€$ логічним і доцільним, однак потребують уточнення й узгодження норми законодавства про освіту з тими вимогами, які містяться у кваліфрікаційних довідниках та інших нормативних актах, які визначають професійний рівень і необхідні компетентності для таких працівників.

Ураховуючи основні напрями фармацевтичної діяльності, щодо кожного її виду закріплені свої ліцензійні умови її здійснення, які включають зокрема й певні кваліфікаційні вимоги до персоналу. Наприклад, щодо виробництва лікарських засобів, відповідно до "Ліцензійних умов провадження господарської діяльності 3 виробництва лікарських засобів, оптової та роздрібної торгівлі лікарськими засобами, імпорту лікарських засобів (крім активних фрармацевтичних інгредієнтів)" [2], ліцензіат повинен мати кваліфікований персонал із практичним досвідом роботи в кількості, що забезпечує належне виконання всіх завдань, пов'язаних із його діяльністю. У зв'язку з цим ліцензіат повинен затвердити організаційну схему й посадові інструкції.

Ліцензійні вимоги до провадження господарської діяльності з оптової торгівлі лікарськими засобами також включають обов'язок ліцензіата мати кваліфікований персонал у кількості (залежно від кількості й потужності аптечних складів), що дає змогу ви- 
конати всі завдання, покладені на ліцензіата. Для цього в ліцензіата повинні бути затверджені штатний розклад та посадові інструкції працівників, у яких зазначені основні функції, повноваження, професійні знання, компетенція й інші вимоги до працівників. У ліцензійних умовах щодо вказаної категорії фармацевтичних працівників зазначено, що особи, які безпосередньо здійснюють оптову торгівлю лікарськими засобами, повинні мати:

1) документ про вищу освіту не нижче першого (бакалаврського) рівня за спеціальністю "Фармація";

2) для фрахівців із вищою освітою не нижче другого (магістерського) рівня - сертифрікат провізора-спеціаліста, виданий закладом післядипломної освіти, або посвідчення про присвоєння (підтвердження) відповідної кваліфрікаційної категорії;

3) посади завідувачів аптечного складу (бази), заступників завідувачів аптечного складу (бази) можуть заміщатися особами, які мають документ про вищу освіту не нижче другого (магістерського) рівня за спеціальністю "Фармація" та сертифікат провізора-спеціаліста за спеціалізацією "Організація та управління фармацією" або атестовані за цією спеціалізацією з присвоєнням (підтвердженням) відповідної категорії.

Ліцензійні вимоги щодо роздрібної торгівлі лікарськими засобами та щодо провадження господарської діяльності з виробництва (виготовлення) лікарських засобів в умовах аптеки вказують на те, що аптеки та їхні структурні підрозділи повинні мати укомплектований штат працівників, які мають відповідну формацевтичну освіту. Ліцензіатом затверджуються посадові інструкції працівників, діяльність яких безпосередньо пов'язана з виробництвом (виготовленням) лікарських засобів в умовах аптеки, роздрібною торгівлею лікарськими засобами, у яких зазначаються основні функції, повноваження, професійні знання, компетенція й інші вимоги до працівників.

У ліцензійних умовах щодо вказаної категорії фрармацевтичних працівників зазначено, що особи, які безпосередньо здійснюють виробництво (виготовлення) лікарських засобів в умовах аптеки, роздрібну торгівлю лікарськими засобами, повинні мати:

1) документ про вищу освіту не нижче першого (бакалаврського) рівня за спеціальністю "Фармація";

2) для фахівців із вищою освітою не нижче другого (магістерського) рівня - сертиорікат провізора-спеціаліста, виданий закладом післядипломної освіти, або посвідчення про присвоєння (підтвердження) відповідної кваліфікаційної категорії;

3) відпуск лікарських засобів можуть здійснювати провізори-спеціалісти, клінічні провізори та фрармацевти з дотриманням вимог законодавства;

4) посади завідувачів аптеки, заступників завідувачів аптеки заміщуються особами, що мають документ про вищу освіту не нижче другого (магістерського) рівня за спеціальністю "Фармація" та сертифікат провізораспеціаліста за спеціалізацією "Організація та управління фармацією" або атестовані за цією спеціалізацією 3 присвоєнням (підтвердженням) відповідної категорії та стаж роботи за фахом не менше двох років. Щодо аптек, розташованих у селах, селищах і селищах міського типу, посади завідувача аптеки, заступника завідувача аптеки можуть обіймати особи, що мають документ про вищу освіту не нижче першого (бакалаврського) рівня за спеціальністю "Фармація". Не допускається обіймання посади завідувача аптечного закладу за сумісництвом.

Ліцензійні вимоги до провадження господарської діяльності з імпорту лікарських засобів (крім активних фрармацевтичних інгредієнтів) вказують, що для виконання вимог належної виробничої практики, що стосуються імпорту лікарських засобів, необхідно мати навчений персонал, що має необхідну кваліфіка- цію в кількості, що дає змогу виконати всі завдання, покладені на ліцензіата. Персонал повинен знати й дотримуватися вимог належної виробничої практики, належної практики дистрибуції, належної практики зберігання, що стосуються його діяльності, а також пройти навчання відповідно до його обов'язків, включаючи інструктаж із виконання гігієнічних вимог. Ліцензіат повинен забезпечити періодичне навчання персоналу, діяльність якого може вплинути на якість продукції, відповідно до затверджених ліцензіатом навчальних програм.

До керівного персоналу належать уповноважена особа й керівник підрозділу контролю якості, якщо уповноважена особа не відповідає за обов'язки керівника підрозділу з контролю якості. Керівний персонал має працювати в режимі повного робочого дня відповідно до внутрішнього трудового розпорядку.

Кваліфікаційні вимоги до фрармацевтичних працівників, що містяться в ліцензійних умовах щодо здійснення різних видів фрармацевтичної діяльності, потребують узгодження із кваліфікаційними вимогам, що містяться в інших нормативних актах, зокрема і в "Довіднику кваліфікаційних характеристик професій" [4]. "Ліцензійні умови провадження господарської діяльності з виробництва лікарських засобів, оптової та роздрібної торгівлі лікарськими засобами, імпорту лікарських засобів (крім активних фрармацевтичних інгредієнтів)" [2] $є$ одним із основоположних нормативних актів, що визначають організацію та здійснення фармацевтичної діяльності, тому кваліфікаційні вимоги, що містяться в Довіднику, можуть опинитися на другому місці, що, із погляду призначення вказаного нормативного акту, $€$ нелогічним. Кваліфрікаційні характеристики професій, що належать до фармацевтичної діяльності, повинні узгоджуватися із законодавством про освіту. Запровадження такої категорії як "професійний стандарт" і нової "Методики розроблення професійних стандартів" [7] дозволили максимально уніфікувати освітні та професійні стандарти, результатом чого повинна стати відповідність освіти вимогам роботодавців до професійних якостей потенційної робочої сили. Професійні стандарти $є$ більш широкою категорією, яка "обслуговує" освітні стандарти та визначає кваліфрікаційні вимоги до професійних кадрів.

Законодавство не містить визначення фармацевтичної діяльності та фармацевтичних працівників. Однак, виходячи з ліцензійних умов, які в багатьох аспектах визначають трудо-правовий статус фармацевтичних працівників, наприклад, окрім кваліфікаційних вимог, містять професійні посадові права й обов'язки працівників, вимоги до умов праці, норми з охорони праці, норми з дисципліни праці та ін. Досліджуючи зміст ліцензійних умов, важливість для сфери охорони здоров'я фармацевтичної діяльності, рівень відповідальності фармацевтичних працівників, можемо припустити, що фармацевтичні працівники працюють виключно на підставі трудового договору, що призводить до виникнення всіх юридичних наслідків, які тягнуть за собою трудові правовідносини. Отже, до фармацевтичних працівників належать професіонали і фахівці, які працюють на підставі трудового договору у сфері виробництва, оптової (роздрібної) торгівлі й імпорту лікарських засобів і відповідають ліцензійним та іншим нормативним вимогам, що врегульовують організацію та функціонування фрармацевтичної діяльності.

На формування кваліфікаційних вимог до фармацевтичних працівників суттєвий вплив здійснює активна діяльність міжнародних організацій, які, зокрема, співпрацюють із нашими національними фармацевтичними організаціями.

Міжнародна фармацевтична федерація (International Pharmaceutical Federation, FIP) - Всесвітня федерація національних фрармацевтичних (наукових) асоціацій, 
має статус неурядової організації, що співпрацює 3 BOO3 (WHO). Завданням такої організації $€$ представлення інтересів фармації та фрармацевтичної науки в усьому світі. До складу федерації входять як фрармацевти, які працюють в аптечних закладах, так і вчені в галузі фармації. У 2015 р. до Міжнародної фармацевтичної фредерації було прийнято першого організаційного члена з України - громадську організацію "Всеукраїнська фармацевтична палата".

ВИСНОВКИ.

Міжнародні організації спільно з національними постійно займаються питаннями розробки й удосконалення глобальної моделі компетенцій для працівників фрармацевтичної галузі. Фармацевтична діяльність $€$ важливою складовою сфери охорони здоров'я, що тісно пов'язана з медичною й реабілітаційною діяльністю. Належне функціонування фрармацевтичної сфери $€$ також передумовою надання якісних медичних і реабілітаційних послуг. Професійність під час здійснення всіх видів фармацевтичної діяльності та забезпечення і підтримання високої кваліфрікації і професійної компетентності фармацевтичних кадрів повинно бути першочерговим завданням держави, що належить до підтримки й розвитку сфери охорони здоров'я.

Отже, існує необхідність удосконалення чинного законодавства у сфрері регулювання фрармацевтичних відносин і розроблення дієвих юридичних механізмів забезпечення ефективного контролю за такою діяльністю. Необхідним є прийняття спеціального закону про формацевтичну діяльність; законодавче визначення фармацевтичної діяльності з основними ії̈ ознаками; законодавче визначення всіх основних видів фармацевтичної діяльності, умов ії̈ здійснення та суб'єктів; детальна регламентація правового та трудо-правового статусу фрармацевтичних працівників; особлива увага та контроль повинен приділятися питанням визначення кваліфікації фрармацевтичних працівників, підтримці їхнього безперервного професійного навчання та встановленню якісного контролю за якістю їх роботи.

Нині діючі "Ліцензійні умови провадження господарської діяльності з виробництва лікарських засобів, оптової та роздрібної торгівлі лікарськими засобами, імпорту лікарських засобів (крім активних фрармацевтичних інгредієнтів)" є підзаконним нормативним актом, який закріплює ряд важливих для врегулювання питань здійснення фрармацевтичної діяльності, але більшість питань потребують упорядкованого визначення та закріплення на рівні Закону з подальшим окремим детальним врегулюванням на рівні підзаконних нормативних актів.

Список використаної літератури

1. Закон України "Про лікарські засоби" від 4 квітня 1996 р. // Вiдомості Верховної Ради України (ВВР). - 1996. - № 22. - Ст. 86. [Елек- тронний ресурс]. - Режим доступу: https://zakon.rada.gov.ua/laws/show/ 123/96-\%D0\%B2\%D1\%80\#Text

2. Ліцензійні умови провадження господарської діяльності з виробництва лікарських засобів, оптової та роздрібної торгівлі лікарськими засобами, імпорту лікарських засобів (крім активних фрармацевтичних інгредієнтів) / Затверджено Постановою Кабінету Міністрів України від 30 листопада 2016 р. № 929. [Електронний ресурс]. - Режим доступy: https://zakon.rada.gov.ua/laws/show/929-2016-\%D0\%BF\#Text

3. Закон України "Основи законодавства України про охорону здоров'я" від 19 листопада 1992 р. // Відомості Верховної Ради України (BВP). - 1993. - № 4. - Ст. 19. [Електронний ресурс]. - Режим доступy: https://zakon.rada.gov.ua/laws/show/2801-12\#Text

4. Довідник кваліфікаційних характеристик професій. Наказ Міністерства охорони здоров'я України від 29 березня 2002 року. - № 117. Вип. 78. [Електронний ресурс]. - Режим доступу: https://zakon.rada.gov.ua/ rada/show/va117282-02\#Text

5. Класифікатора професій (ДК 003:2010): Наказ Держспоживстандарту України від 28 липня 2010 р. № 327. [Електронний ресурс]. Режим доступу: https://zakon.rada.gov.ua/rada/show/va327609-10\#Text

6. Перелік вищих медичних навчальних закладів, підготовка і отримання звання в яких дають право займатися медичною і фармацевтичною діяльністю: Наказ Міністерства охорони здоров'я України від 25 грудня 1992 р. - № 195. [Електронний ресурс]. - Режим доступy: https://zakon.rada.gov.ua/rada/show/v0195282-92\#Text

7. Методика розроблення професійних стандартів / Затверджена Наказом Міністерства соціальної політики України від 22 січня 2018 р. № 74. [Електронний ресурс]. - Режим доступу: https://zakon.rada.gov.ua/ laws/show/z0165-18\#Text

\section{References}

1. Pro likars'ki zasoby, Zakon Ukrai'ny [On Medicinal Products, Law of Ukraine] № 123/96-VR (1996). Vidomosti Verhovnoi' Rady Ukrai'ny [Information of the Verkhovna Rada of Ukraine], (22), 86 (in Ukrainian).

2. Licenzijni umovy' provadzhennya gospodars'koyi diyal'nosti z vy'robny'cztva likars'ky'x zasobiv, optovoyi ta rozdribnoyi torgivli likars'ky'my' zasobamy', importu likars'ky'x zasobiv (krim akty'vny'x farmacevty'chny'x ingrediyentiv), postanova Kabinetu Ministriv Ukrayiny' № 929 (2016). https://zakon.rada.gov.ua/laws/show/929-2016-\%D0\%BF (in Ukrainian).

3. Osnovy' zakonodavstva Ukrayiny' pro oxoronu zdorov'ya, Zakon Ukrayiny' [Fundamentals of Ukrainian legislation on health care, Law of Ukraine] (1992). Vidomosti Verxovnoyi Rady' Ukrayiny [Information of the Verkhovna Rada of Ukraine], (4), 19 (in Ukrainian).

4. Dovidny'k kvalifikacijny'x xaraktery'sty'k profesij. Vy'pusk 78 "Oxorona zdorov'ya", Nakaz Ministerstva oxorony' zdorov'ya Ukrayiny'[Handbook of qualification characteristics of professions. Issue 78 "Health Care", Order of the Ministry of Health of Ukraine] №117 (2002). https://zakon.rada.gov.ua/ rada/show/va117282-02\#Text (in Ukrainian).

5. Klasy'fikatora profesij (DK 003:2010), Nakaz Derzhspozhy'vstandartu Ukrayiny'[Classifier of professions (DK 003: 2010), Order of Derzhspozhyvstandart of Ukraine] № 327 (2010). https://zakon.rada.gov.ua/ rada/show/va327609-10\#Text (in Ukrainian).

6. Perelik vy'shhy'x medy'chny'x navchal'ny'x zakladiv, pidgotovka i otry'mannya zvannya $v$ yaky'x dayut' pravo zajmaty'sya medy'chnoyu i farmacevty'chnoyu diyal'nistyu, Nakaz Ministerstva oxorony' zdorov'ya Ukrayiny' [The list of higher medical educational institutions, preparation and obtaining of a title in which give the right to be engaged in medical and pharmaceutical activity, Order of the Ministry of Health of Ukraine] № 195 (1992). https://zakon.rada.gov.ua/rada/show/v0195282-92\#Text (in Ukrainian).

7. Metody'ka rozroblennya profesijny'x standartiv, Nakazom Ministerstva social'noyi polity'ky' Ukrayiny' [Methodology for developing professional standards, Order of the Ministry of Social Policy of Ukraine] № 74 (2018). https://zakon.rada.gov.ua/laws/show/z0165-18\#Text (in Ukrainian).

Received: $14 / 01 / 2021$

1st revision: $08 / 02 / 2021$

Accepted: $18 / 02 / 2021$

T. Vakhonieva, Dr of Law, Prof.

Taras Shevchenko National University of Kyiv, Kyiv, Ukraine

\section{LEGAL STATUS AND QUALIFICATION REQUIREMENTS FOR PHARMACEUTICAL WORKERS}

The article examines the features of the legal status of pharmaceutical workers and determines the place of pharmaceutical activity in the field of health care. Pharmaceutical workers are considered as a separate category of health workers, along with medical workers and workers working in the field of rehabilitation. The qualification requirements to pharmaceutical workers fixed by the legislation depending on the sphere and type of pharmaceutical activity are determined. Pharmaceutical workers include professionals and specialists who work on the basis of an employment contract in the field of production, wholesale (retail) and import of medicines and meet the licensing and other regulatory requirements governing the organization and operation of pharmaceutical activities. Some licensing conditions for the implementation of various types of pharmaceutical activities and the relationship of their standards with other regulations are investigated.

The need to improve the current legislation in the field of regulation of pharmaceutical relations and the development of effective legal mechanisms to ensure effective control over such activities is pointed out. It is necessary to adopt a special law on pharmaceutical activities; legislative definition of pharmaceutical activity with its main features; legislative definition of all main types of pharmaceutical activity, conditions of its implementation and subjects; detailed regulation of the legal and labor status of pharmaceutical workers. Particular attention and control should be paid to determining the qualifications of pharmaceutical workers, supporting their continuing professional education and establishing quality control over the quality of their work.

Keywords: pharmaceutical activity, pharmaceutical workers, qualification requirements, qualification characteristics, licensing requirements. 